\title{
Invisible production spaces in metropolitan areas: uncovering micro-urban manufacturing in the case of São Paulo, Brazil
}

\author{
Espaços de produção invisíveis em áreas metropolitanas: \\ revelando a micromanufatura urbana no caso de São Paulo, Brasil
}

Giselle Kristina Mendonça Abreu [l]

\begin{abstract}
Resumo
A manufatura em áreas metropolitanas tem sofrido drásticas transformações. Por meio de um estudo de caso realizado em São Paulo, Brasil, este artigo fornece novos insights para debates sobre economias urbanas, lançando luz sobre a micromanufatura urbana - uma atividade que, apesar de muito difundida, não costuma ser incluída na teoria e nos discursos de planejamento. Inicialmente, delimito o debate de maneira ampla, reconstituindo a relação entre atividade econômica e desenvolvimento urbano no processo histórico de construção de São Paulo. Em seguida, analiso o segmento de micromanufatura no contexto da manufatura como um todo, ressaltando sua relevância, ubiquidade e resiliência. Finalmente, examino as próprias atividades de micromanufatura, apontando sua heterogeneidade e a existência de duas geografias, dependendo do setor de manufatura.
\end{abstract}

Palavras-chave: desenvolvimento econômico urbano; micromanufatura urbana; planejamento urbano; São Paulo.

\begin{abstract}
Manufacturing in metropolitan areas has been drastically transformed. This case study of São Paulo, Brazil contributes new insights to debates about urban economies by shedding light on micro-urban manufacturing - an activity that, despite its pervasiveness, is usually left out of planning theory and discourses. First, I broadly frame this debate by retracing the relationship between economic activity and urban development in the historical making of São Paulo. Second, I analyze micromanufacturing as a segment within the broader context of manufacturing, highlighting its relevance, ubiquity, and resilience. Next, I examine micro-manufacturing activities by themselves and point out at their heterogeneity. Finally, I describe the emergence of two unique geographies of micro-urban manufacturing in the city.
\end{abstract}

Keywords: urban economic development; micro-urban manufacturing; urban planning; São Paulo. 


\section{Introduction}

When we think about metropolitan industrial spaces, our collective imaginaries quickly assemble a landscape of smokestack buildings, with extensive production floors and heavy machinery. Even though this might ring true for a few of the manufacturing sectors, the reality is that most of them have been drastically transformed. Manufacturing in contemporary cities is now far more knowledge-based and technologicallyadvanced, with leaner production areas, less pollution and noise, and more integration with other urban uses (Daniels and Bryson, 2002). Neoliberal and globalized capitalism have highly impacted manufacturing activities in cities and transformed the role of cities in global economies (Sassen, 2001). Structural change in the predominant mode of production accompanies technological advances: first, we witnessed the deindustrialization of large cities as manufacturing plants moved around the globe; second, a new flexible and more ondemand mode of production fragmented the production process into smaller units that are connected through networks of outsourcing (Scott, 1988).

This new landscape of manufacturing calls for a refreshed look into its activities and role in contemporary metropolitan areas. I contribute to the debate on urban economies by arguing that there's a missing piece to the puzzle: micro-urban manufacturing. Microurban manufacturing has been largely invisible in both planning research and practice. The field of urban studies, particularly in Brazil, has been dominated by narratives of global restructuring processes. These narratives highlight the process of deindustrialization, which large metropolitan areas face all over the world. Furthermore, metropolitan deindustrialization displaces large-scale factories to areas where the workforce and land are cheaper. In the U.S., for example, millions of jobs have moved to China. Scholars in São Paulo, however, focus on understanding the process of decentralization, where manufacturing moves from the metropolitan region to other cities upstate (Araújo, 2001). Therefore, as a provocation, I ask: how can we reframe our theories and thinking about the economy of cities and metropolitan areas by incorporating an understanding of small-scale economic activity?

Planning practices tell a similar story. For decades, the main urban planning tools used in São Paulo to guide urban growth and promote the well-being of local communities have been master plans and zoning ordinances. These tools directly engage large-scale industrial areas or big businesses while overlooking small-scale production areas as an important component of the urban economy and neighborhood vitality (Mendonça Abreu, 2017). Perhaps this can be attributed to misinformation or inappropriate tools to deal with a fragmented landscape of small-scale production. In any case, I again ask: alternatively, how can our planning practices engage and promote local and small-scale manufacturing units? The answers to these questions are beyond the scope of this paper; nevertheless, I use them as motivations for undertaking this study on these invisible activities in the city. 
The objective here is to develop a preliminary and exploratory examination of primary data on micro-urban manufacturing activities in the context of a metropolitan area in the Global South (São Paulo, Brazil), aiming at contributing new insights to liven up debates on urban economies. First, I broadly frame this debate by retracing the relationship between economic activity and urban development in the historical making of the City of São Paulo. Second, I analyze the specific segment of micro-urban manufacturing in the broader context of manufacturing, highlighting the relative relevance, ubiquity, and resilience of small production spaces in the city. Lastly, I examine micro-urban manufacturing by itself, pointing out the existence of two geographies (spatial distributions), depending on the manufacturing sector.

\section{Definition}

In this study, I adopt two different statistical definitions of micro-urban manufacturing, depending on the database. For economic activity data, I consider micro-urban manufacturing a manufacturing business that has 1-20 employees, which is the definition used by Sebrae. ${ }^{1}$ When dealing with land use data, I consider micro-urban manufacturing a lot with a built area of up to $500 \mathrm{~m}^{2}$, which is the threshold defined by local zoning laws for manufacturing use to be allowed in most areas of the city (not only in industrial zones).

Additionally, I employ the qualifier urban to highlight that these activities are located within the urban fabric, in multiple neighborhoods - not just traditionally industrial zones - and that production is oriented towards final consumers who live in cities. Manufacturing solely refers to industries of transformation, which do not include transportation, utilities services, or construction sectors.

\section{Data}

The three main data sources for this study are (1) land use data from the municipality of São Paulo; (2) data on formal businesses collected by the federal government of Brazil, and provided by the municipality; ${ }^{2}$ and (3) census sample data, also organized and provided by the municipality.

The land use database is georeferenced and contains each lot registered with the municipality for tax purposes. The source of the original database is the Land and Building Registry (TPCL, the Portuguese acronym). Each lot contains, among other attributes, the built area and land use, which is categorized into general classes (e.g., residential, retail, and manufacturing). Reaching almost 18 million $\mathrm{m}^{2}$, manufacturing land use accounts for $4 \%$ of the total built area of the city.

The original dataset on formal businesses, the Annual Report of Social Information (RAIS, the Portuguese acronym), includes information on size, employees, revenue, and other factors that are self-reported by businesses to the federal government. Due to confidentiality agreements, the dataset is not disclosed in disaggregated form - the municipality can only provide aggregated data by clusters of census tracts, or weighting areas (áreas de ponderação, in Portuguese). Upon request, 
I was able to obtain data on the number of micro-manufacturing businesses, which are divided by sector, for each of the municipality's 310 weighting areas.

Lastly, I use the most recent 2010 census data to track down the education level and commute time of workers from different manufacturing sectors. Working with sample data necessitated expanding the data to the total population through the use of the census weighting areas. It's important to mention that census and RAIS databases use slightly different classifications of economic sectors. Therefore, some variation might occur due to the dataset used. To the extent possible, I have tried to standardize these categories.

\section{Historical overview of São Paulo's economy and urban development ${ }^{3}$}

Historically, economic dynamics have always impacted the settlement patterns and spatial organization of cities. Seminal studies on the history of the City of São Paulo have pointed to this link, seeking in economic geography and history the baselines from which to explain São Paulo's urban development (Monbeig, 2004; Prado Jr., 1998; Singer, 2004). I will briefly retrace this history to provide the necessary context for my empirical investigation, as well as a critical perspective on existing gaps.

The period that extends from the foundation of the town of São Paulo de Piratininga until the second half of the nineteenth-century is defined by a subsistence economy. With the gold cycle in Minas Gerais, a neighboring state, the town gained more prominence as a commercial hub, due to its strategic location at the intersection of the tropeiros' paths. During the last decades of the nineteenth-century, coffee production in the interior of the State of São Paulo expanded from $16 \%$ to $40 \%$ of the total national economic output. With the inauguration of a railway connection between São Paulo and Santos in 1868, São Paulo became an even more important link between the coffee farms and Santos's port of export (Singer, 2004). The coffee cycle, extending until the 1920s, marks a critical period in the city's history, which promotes a significant inflection in the urbanization process and creates the conditions for industrialization.

The process of industrialization timidly began at the start of the twentieth-century, with small sewing and weaving factories founded by Italian and Lebanese immigrants who settled close to the city center, though on the other side of river Tamanduateí, as described by Monbeig (2004) and Singer (2004). There are two main reasons why manufacturing initially settled in São Paulo: (1) as we saw before, the city was close to the port of Santos, where raw materials entered the country and production was exported; and (2) São Paulo had become the center of communications and gathered a growing pool of consumers and workers. Rich coffee farmers' families came to live in the city while a new workforce became available. This workforce comprised the previously enslaved population that was freed in 1888 and waves of immigrants who were able to make wages and engage in consumption (Prado Jr., 1998). This process was intensified from the 1930s to 1950 s due to a national policy of import 
substitution and two world wars that paralyzed European industry and reduced the availability of imports.

Since the beginning of the twentiethcentury, the fluvial plains of the city's main rivers - Tietê, Tamanduateí, and Pinheiros have been the preferred industrial sites. The triad formed by the railroad, flat and cheap land, and abundance of water provides the ideal conditions for the settlement of São Paulo's industrial areas. Initially, factories settled along the Tamanduateí river, on the opposite bank to the historic city center. Later, they expanded towards other municipalities of the metropolitan region, and to the banks of Pinheiros river, forming the industrial districts of Jaguaré and Jurubatuba.

The 1950s onward brought a process of "heavy" industrialization, with the arrival of factories from more technologically-intensive industries that produced machinery and equipment. Industries of consumer goods were replaced by industries of capital goods as the main drivers of the urban economy. ${ }^{4}$ This shift relates to the developmental policy promoted by Brazil's National Administration under Juscelino Kubitschek (1956-1961). Industrialization was followed by intense migratory flows - rural workers looking for employment opportunities in the growing city - that led to a drastic expansion of the urban population during this period and characterized the process of the "metropolitanization" of São Paulo. ${ }^{5}$

In general, there is a consensus in the literature about the economic history of São Paulo until the mid-1970s, how each of these previous moments can be understood and characterized, and how their role in driving the urbanization process should be framed. However, after reaching the peak of its industrialization in the 1970s, there was a strong slowdown in the dynamics of manufacturing in São Paulo; here is where the literature diverges. The process that unfolded during the three decades has been interpreted in quite different ways.

On the one hand, there are authors who interpret this dynamic of industrial decline as an irreversible transformation of the metropolitan economic base from secondary to tertiary, anchored in the process of deindustrialization (Biderman, 2004; Meyer, Grostein and Biderman, 2004). For Biderman, "the city increasingly presents a functional specialization of corporate headquarters, business services, and industries that serve the first two, rather than the [manufacturing] concentration that characterized it in the 1970s" (Biderman, 2004, p. 268, my translation). For the author, even the manufacturing businesses that remain in the metropolis are vitalized by the tertiary sector, which reinforces their centrality in the economy. This understanding is mainly based on an analysis of workforce data, which clearly shows a sharp decline in the share of manufacturing jobs in relation to total employment in the city, and a considerable increase in service sector jobs. Even if we only look at the period from 2000 to 2014, for which there's easily accessible data on the number of formal businesses, jobs, and GDP by sector, this detachment of trends is clear, with the services sector abruptly rising (Figure 1).

Others, on the other hand, offer alternative perspectives (Araújo, 2001; Azzoni apud Torres, 2012). They claim that the process we are observing cannot be properly described 
Figure 1 - Economic trends: companies, jobs and GDP by sector City of São Paulo, 2000-2014
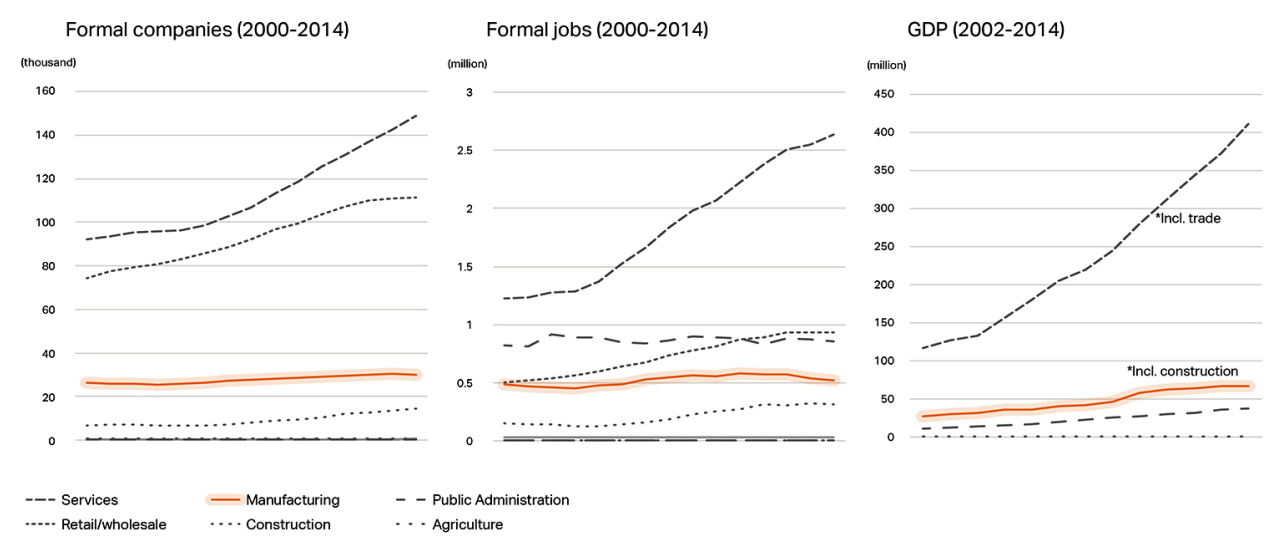

Source: Companies and jobs - RAIS/MTE, 2000-2014; GDP - IBGE/Fundação Seade, 2000-2014. Preparation by: Mendonça Abreu, 2017.

as "deindustrialization" of the metropolitan economy. Looking at the national economic dynamics, Azzoni argues that the process is not about the decentralization of manufacturing throughout the entire national territory or even abroad, but instead it is about the continuation of manufacturing businesses close to the metropolitan region. In other words, even if manufacturing businesses are not inside the capital city anymore, they are still located in municipalities close by, within what is called the "macrometropolis of São Paulo" (Azzoni apud Torres, 2012). The author also points out that this process is related to the location of command-and-control business headquarters in the metropolitan area, further strengthening the City of São Paulo's continued centrality within national industrial development.

In addition, Araújo (2001) argues that what happened in the metropolitan area of São Paulo was a process of industrial restructuring due to structural transformations in production processes such as outsourcing of activities, reduction in the number of formal employees, and technological innovation. This interpretation makes it possible to explain the statistical migration of a portion of workers from the secondary to the tertiary sector. Even though many jobs are now classified as "services," she argues, their activities are still closely related to the manufacturing sector. Matteo (2007) also highlights that manufacturing "keeps growing" in São Paulo and that we are now seeing a transformed activity that no longer corresponds to large industrial plants, but rather to leaner and capital-intensive factories, with more technology and integration with the services sector. He thus refutes Biderman's hypothesis, by stating that "the metropolis of São Paulo is 
still a region that has its economic dynamism conceded by manufacturing, not by services" (Matteo, 2007, p. 4, my translation).

This brief overview of how the City of São Paulo's economy has been interpreted, particularly with multiple considerations given to the role of manufacturing activity in the urban economy, only highlights how scholarly discussions about the city's economy are still mostly restricted to large-scale processes and "big" numbers. Most of these studies are coming from a regional economy tradition in which data is usually aggregated for the whole of the municipality - the urban fabric is lost, and the heterogeneity of manufacturing activity is occluded in these analyses. There are rare studies that focus on understanding economic activities within the intra-urban scale, or that consider the diversity of manufacturing activities and the ways in which they are embedded within the city. It is precisely the recognition of this gap that motivates this paper. In what follows, my goal is to uncover a mostly invisible component of this larger equation: the sector of micro-urban manufacturing. My aim is to contribute insights that challenge common understandings of the role of manufacturing in the city's economy.

\section{Representation and significance of micro-urban manufacturing}

In this section, I argue that micro-urban manufacturing in São Paulo is a specifically relevant segment of economic activity since (1) it represents a significant part of the total industrial manufacturing sector, (2) it is intrinsically and ubiquitously embedded in the urban fabric, and (3) it has demonstrated resilience in the face of economic crises.

\section{Participation}

Micro-urban manufacturing has been largely invisible to discourses of the urban economy. In fact, when you look at the participation of micro and small businesses ${ }^{6}$ in the Brazilian economy, their role in the economic output of the manufacturing sector is lower than the share that micro and small businesses hold in retail or services. In manufacturing, micro and small businesses produce around $25 \%$ of the sector's national GDP, while they account for $53 \%$ in retail and $36 \%$ in services (Sebrae, 2014). If you consider only micro businesses, the share is significantly lower: micro businesses account for only $9 \%$ of the manufacturing sector's national GDP (Ibid.). However, their presence in the urban fabric and their participation in the economy is far from insignificant.

The distribution of land use in the City of São Paulo reveals that $50 \%$ of lots with manufacturing use are small production spaces, with a built area of less than $500 \mathrm{~m}^{2}$ (Table 1.1). When looking at formal businesses within the metropolitan area, the numbers are also impressive: micro businesses represent $80 \%$ of the total number of manufacturing businesses and around $20 \%$ of jobs (Table 1.2). Even though the high percentage related to the number of businesses might have been expected - considering that we are looking at really small companies which tend to be larger in number - it's interesting that despite being so small in individual scale, they account for one-fifth of jobs. This is a significant portion 
Table 1 - Manufacturing lots, firms, and jobs - São Paulo, 2016

1.1 - Lots with manufacturing use by built area - City of São Paulo, 2016

\begin{tabular}{|l|c|c|}
\hline \multicolumn{1}{|c|}{ Built area } & $\begin{array}{c}\text { \# of lots with } \\
\text { manufacturing } \\
\text { use }\end{array}$ & $\begin{array}{c}\text { Participation } \\
\%\end{array}$ \\
\hline Up to $500 \mathrm{~m}^{2}$ & 6.718 & 50,0 \\
\hline Between 500 and $2.500 \mathrm{~m}^{2}$ & 5.416 & 40,3 \\
\hline Between 2.500 and $10.000 \mathrm{~m}^{2}$ & 1.060 & 7,9 \\
\hline More than $10.000 \mathrm{~m}^{2}$ & 248 & 1,8 \\
\hline Total & 13.442 & 100 \\
\hline
\end{tabular}

Source: TPCL/PMSP, 2016.

Preparation by: Mendonça Abreu.
1.2 - Manufacturing firms and jobs Metropolitan Region of São Paulo, 2016

\begin{tabular}{|l|r|c|c|c|}
\hline \multicolumn{1}{|c|}{$\begin{array}{c}\text { Segment of manufacturing } \\
\text { businesses by size }\end{array}$} & \multicolumn{2}{|c|}{ Formal businesses } & \multicolumn{2}{c|}{ Formal jobs } \\
\cline { 2 - 5 } & \multicolumn{1}{|c|}{$\begin{array}{c}\text { Participation } \\
\%\end{array}$} & $\#$ & $\begin{array}{c}\text { Participation } \\
\%\end{array}$ \\
\hline Firms with 0-20 employees & 35.112 & 81,4 & 182.181 & 20,1 \\
\hline Firms with 20-100 employees & 6.327 & 14,7 & 256.958 & 28,3 \\
\hline Firms with 100-250 employees & 1.021 & 2,4 & 158.060 & 17,4 \\
\hline Firms with 250-500 employees & 462 & 1,1 & 111.081 & 12,2 \\
\hline Firms with more than 500 employees & 199 & 0,4 & 199.479 & 22,0 \\
\hline
\end{tabular}

Source: RAIS/MTE, 2016.

Preparation by: Mendonça Abreu. of manufacturing employment in the city. These numbers are also consistent with the national average. Considering the entire country, micromanufacturing businesses account for $79 \%$ of companies and $17 \%$ of manufacturing jobs (Ibid.).

These numbers reflect only formal businesses that report to the federal government. However, it is known that this segment is also highly informal, so one could extrapolate that the share of micromanufacturing businesses and jobs is, in reality, even larger. The so-called "informal" economy is known for consisting of small firms, usually selfemployed, that aren't regulated by the formal regulatory environment (Castells and Portes, 1989; Tokman, 1992; Williams, 2014). Homebased industrial workers - mostly women - are also another relevant segment of the informal economy that falls outside of the reach of the database used here (Chen, 2014).
These micro-manufacturing units, both formal and informal, are dispersed throughout the urban fabric. They include the neighborhood's bakery, the local metalworking shop, and the sewing cooperative nearby. In many cases, these activities happen in spaces that are themselves informal, participating in a broader process of "urban" informality, understood as a specific mode of urbanization (Roy and Alsayyad, 2004). These micromanufacturing spaces might not be significant producers of economic output when looking at the big picture, but they play a crucial role in structuring the local economy and in diversifying neighborhoods, both in terms of job offerings and land use. The following section demonstrates how they form a dispersed pattern, overflowing the traditional industrial zones and spreading into different corners of the city. 


\section{Ubiquity}

Micro-urban manufacturing not only holds a significant share of the total number of manufacturing lots and businesses in the city, it also has a strong presence in the urban fabric. In contrast to large-scale manufacturing plants, which are mostly concentrated in specific parts of the city, micro businesses are everywhere, composing a pattern that is both dispersed and concentrated (Figure 2). There is a changing geography of industrial production in São Paulo. Several medium- and large-scale manufacturing plants - originally located along the main fluvial plains close to railway lines and expressways - have exited the city and moved to other municipalities around the state (Torres, 2012). At the same time, thousands of small production areas proliferate throughout the urban fabric. The difference in the geographies inscribed in the territory by large- versus micro-manufacturing firms is striking (Figure 3).

This picture adds to the narrative of a new manufacturing landscape in large metropolitan areas that is primarily composed of decentralized networks of small specialized companies that are simultaneously spread out in neighborhoods and hidden from our imaginaries. Particularly in the case of São Paulo, these micro-manufacturing firms have been locating mostly in the eastern area of the city, a region historically characterized by a larger share of medium- and lower-income residents and lack of jobs. This influx of micromanufacturing firms, therefore, helps change the geography of employment distribution (Rolnik and Frúgoli Jr., 2001).

Figure 2 - Urban lots with manufacturing land use City of São Paulo, 2016

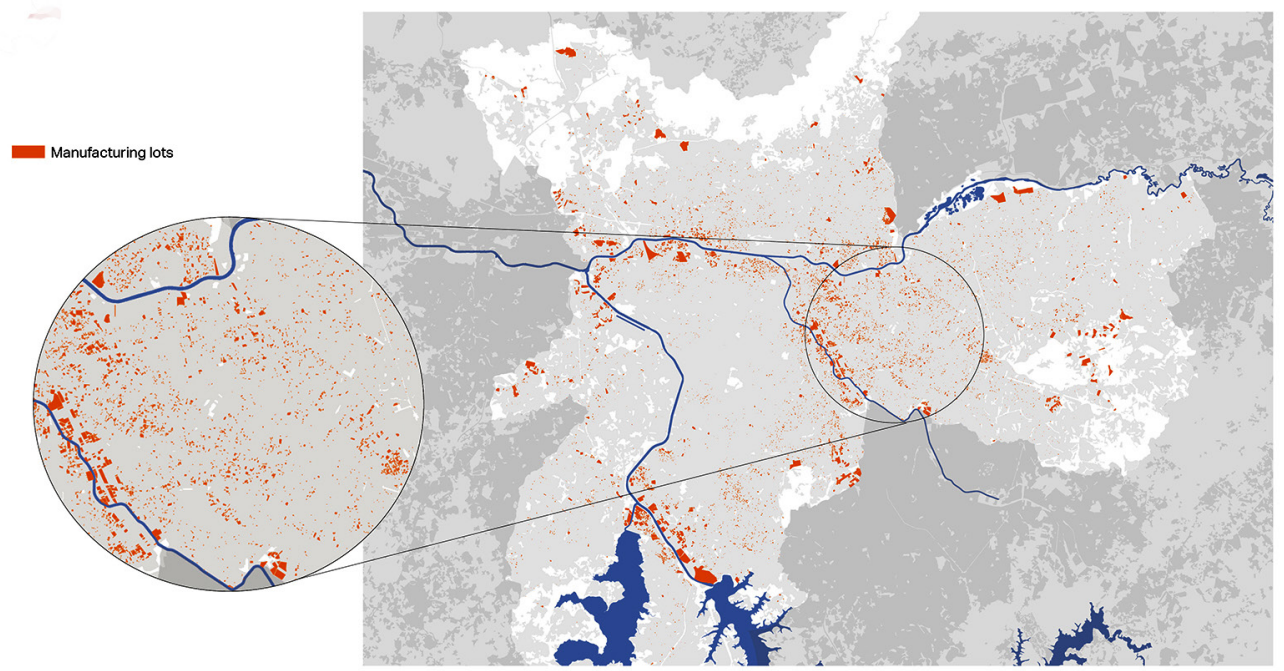

Source: TPCL/PMSP, 2016.

Preparation by: Mendonça Abreu, 2017. 
Figure 3 - Heatmaps of large and micro manufacturing lots City of São Paulo, 2016

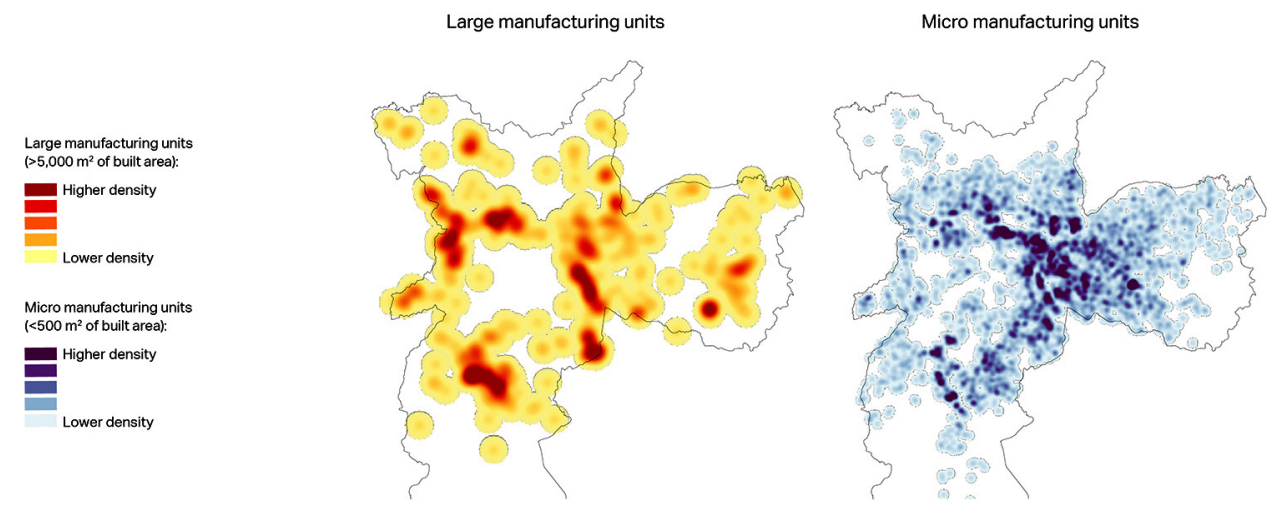

Source: TPCL/PMSP, 2016.

Preparation by: Mendonça Abreu, 2017.

Another important observation is that the spatial distribution of micro-manufacturing lots and the zoning ordinances of the city don't match. Less than $12 \%$ of micro-manufacturing lots are located within current industrial zones (Figure 4 and Table 2). This relationship is distinctly different when considering larger units. Around $40 \%$ of the lots with more than $10,000 \mathrm{~m} 2$ of built area of manufacturing use are located inside industrial zones. There are several reasons why large-scale manufacturing units tend to be more concentrated than micro-manufacturing ones in industrial zones. One reason is the availability of infrastructure and geographical conditions: for large manufacturing plants, it is far more important to be close to main transportation routes (both railway and roadway) to dispatch and receive large quantities of material, and in areas with large flat lands. These are the places where manufacturing activity has historically settled in São Paulo. Additionally, the delimitation of industrial zones has generally reinforced these spaces as industrial districts since the first zoning ordinance of the city, known as "Noise Law", in 1955 (for more on the São Paulo's historical development of zoning ordinances and its relationship to economic activities, see Mendonça Abreu, 2017).

$$
\text { Another key reason why large }
$$
manufacturing firms tend to locate in industrial zones has to do with the restrictions imposed by zoning ordinances. On the one hand, large manufacturing plants tend to be more formalized than micro-firms - where there is a considerable amount of informality - and 
Figure 4 - Manufacturing lots with less than $500 \mathrm{~m}^{2}$ of built area vs. industrial zoning - City of São Paulo, 2016

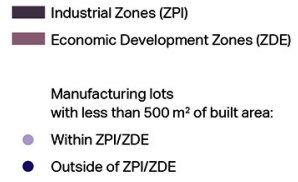

- Outside of ZPIZZDE

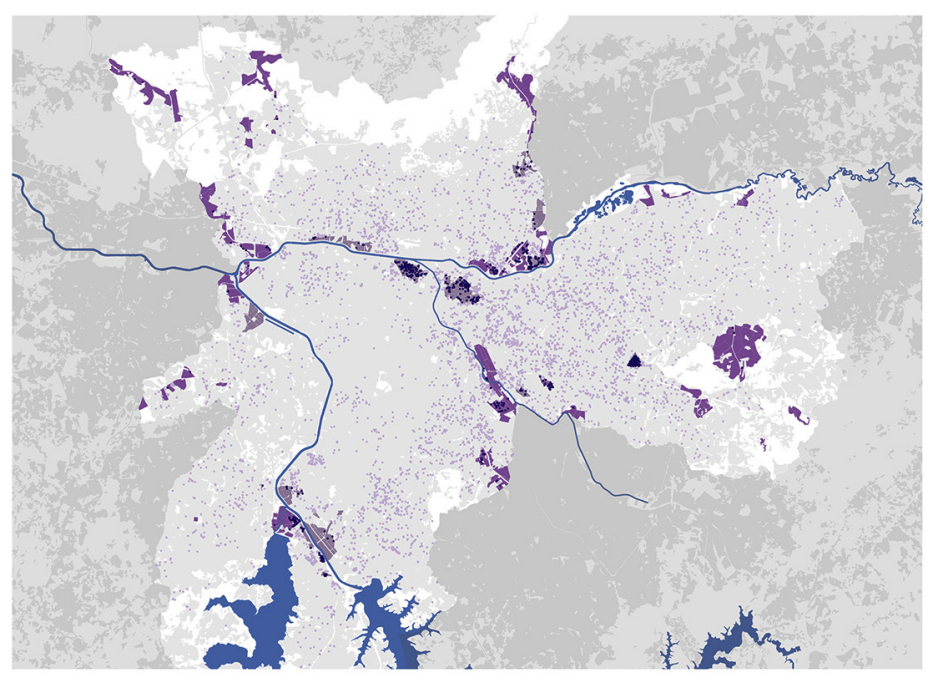

Source: Industrial lots - TPCL/PMSP, 2016. Zoning regulations - Municipal Law 16.402, 2016.

Preparation by: Mendonça Abreu, 2017.

Table 2 - Manufacturing lots, firms and jobs - São Paulo, 2016

\begin{tabular}{|c|c|c|c|c|}
\hline \multirow[t]{2}{*}{ Location } & \multicolumn{2}{|c|}{$\begin{array}{l}\text { Lots with manufacturing use } \\
\text { with } 500 \mathrm{~m}^{2} \text { of built area }\end{array}$} & \multicolumn{2}{|c|}{$\begin{array}{l}\text { Lots with manufacturing use } \\
\text { with nore than } 10.000 \mathrm{~m}^{2} \\
\text { of built area }\end{array}$} \\
\hline & Participation & \# & Participation & \# \\
\hline City of São Paulo (Total) & 6.718 & 100,0 & 248 & 100,0 \\
\hline $\begin{array}{l}\text { Within ZPI (Industrial Zone) or } \\
\text { ZDE (Economic Development Zone) }\end{array}$ & 753 & 11,2 & 100 & 40,3 \\
\hline
\end{tabular}

Source: TPCL/PMSP, 2016; Zoning: Municipal Law 16.402, 2016.

Preparation by: Mendonça Abreu, 2017. 
need to comply with local regulations that impose restrictions on where they can locate in the city. Due to levels of pollution, noise, and traffic generated by these larger units, they are not allowed to settle in most of the residential, commercial, or mixed use zones in the city. Therefore, industrial zones are the only spaces reserved for this activity. On the other hand, the land in industrial zones tends to be much cheaper than in the rest of city: limitations to the maximum FAR (Floor Area Ratio, or coeficiente de aproveitamento in Portuguese) renders this land less valuable to residential real estate development, keeping the land value lower and more accessible to large manufacturing plants.

In contrast, micro-manufacturing firms can be more flexible in terms of their locational decision. First, buildings with manufacturing use and less than $500 \mathrm{~m}^{2}$ of built area are legally allowed by the current zoning law to be located anywhere in the city. This is mainly because the level of disturbance - traffic, noise, and pollution - caused to the surrounding areas is much lower than that caused by larger plants. Additionally, the current zoning law, which was recently reviewed through a participatory process, states that in an effort to halt the decentralization of job opportunities, several restrictions to the installation of economic activities in different parts of the city have been removed (PMSP, 2016).

Second, with only a handful of employees, it makes more sense for micromanufacturing firms to locate closer to where their employees live and in particular closer to where the owner lives. A survey conducted by Sebrae-SP (2015) found that $64 \%$ of microand small-manufacturing firms in the State of São Paulo involve the owner's family in the business. Sebrae's findings underscore why these firms would preferably locate in neighborhoods where the owners, and their families, live. Furthermore, as I describe in more detail in the following section, most of these small businesses sell their products directly to final consumers. Thus, it makes even more sense for them to locate within mixed-use zones that are closer to residential areas.

\section{Resilience}

The well-documented process of the deindustrialization of the City of São Paulo resulted in the displacement of several manufacturing firms from the metropolitan area. This process has been compounded by recent waves of economic crises, both global and national, that have affected multiple sectors of economic activity. Business closures and increasing unemployment rates have arisen as a result. It is interesting to note, however, that this process hasn't been uniform throughout different segments of firm size. While the number of jobs and companies in the manufacturing sector has continued decreasing in most categories of company size since 1995 - and more abruptly since 2010 micro-urban manufacturing, as a segment, has been steadily increasing in number of businesses and jobs.

Looking at trends of growth and decline in the number of firms, the difference is not significantly noticeable. Most segments appear to have stabilized (Figure 5). However, specific percentages are remarkable: from 1995 to 2016, only the micro business segment grew, 
Figure 5 - Trend of manufacturing companies by company size Metropolitan Region of São Paulo, 1995-2016
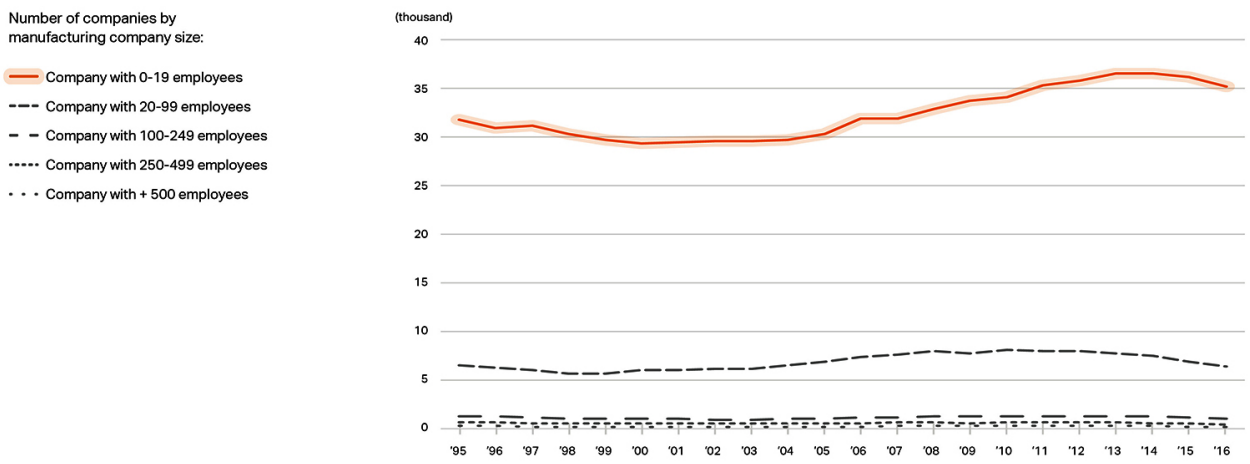

Source: RAIS/MTE, 1995-2016.

Preparation by: Mendonça Abreu, 2017.

with an approximately $10 \%$ increase in number of firms. All the other segments contracted in their number of businesses. Notably, the segment of larger manufacturing firms was the most affected. In this period, São Paulo lost about 260 manufacturing companies with 250-500 employees (a decrease of 36\%) and around 100 companies with more than 500 employees (a decrease of 34\%).

Trends regarding the variation in number of jobs, a critical indicator for economic development, reveal an even more interesting scenario: the segment of micro-manufacturing diverges from trends observed in other segments (Figure 6). There is a strong decrease in the number of jobs from 1995 to 1999, a consequence of the broader debt crisis within the context of economic and trade liberalization policies undertaken by the federal government during this period. In the Metropolitan Region of São Paulo, unemployment increased from $8.7 \%$ to $19.3 \%$ during the 1990 s. In the first decade of the 2000s, on the other hand, there was a strong recovery in the number of manufacturing jobs in the city - But, again, this didn't happen consistently throughout different segments of firm size.

Larger firms didn't reach the original number of employees they had in 1995. This decrease is inversely proportional to company size: manufacturing firms with more than 500 employees faced the largest contraction, losing more than 130,000 jobs between 1995 and 2016 (an impressive decrease of 39\%); Firms with 250-500 employees lost around 64,000 jobs (again, a striking decrease of $36 \%$ ); Firms with 100-250 employees lost 46,000 jobs (a decrease of 7.5\%). Micro-manufacturing 
Figure 6 - Trend of manufacturing jobs in formal manufacturing companies by company size Metropolitan Region of São Paulo, 1995-2016

Number of jobs by manufacturing company size:

- Company with 0-19 employees

--- Company with 20-99 employees

- - Company with 100-249 employees

..... Company with 250-499 employees

... Company with +500 employees

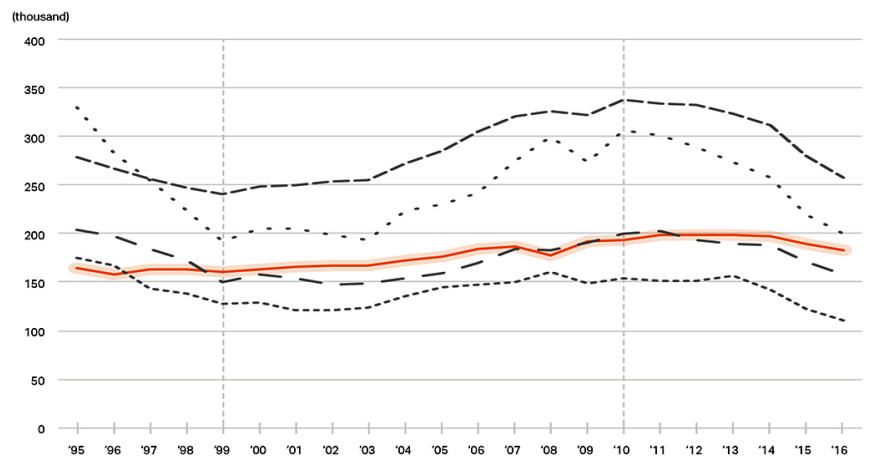

Source: RAIS/MTE, 1995-2016.

Preparation by: Mendonça Abreu, 2017.

companies were the only exception. Contrary to these trends, their number of jobs increased by $10.7 \%$ between 1995 and 2016. However, the scale of this increase in absolute number of jobs wasn't as significant, when compared to the number of jobs lost in medium- and large-scale firms. Only 17,600 jobs were added to the pool of manufacturing jobs in the city in micro-manufacturing firms - possibly some of them due to a process of formalization (i.e., micro-firms entering the formal market and registering previously informal workers).

Nevertheless, the segment of micro-urban manufacturing has been significantly resilient throughout the past 20 years. During the critical decade of the 1990s, the number of jobs offered by micro-manufacturing companies didn't decrease at all. Furthermore, it grew steadily throughout the following years. In order to fully analyze this phenomenon, additional data on the survival rates of establishments are needed since micro-businesses can fail very easily after they open. Therefore, this overall pattern of resilience might occlude individual difficulties to survive and thrive in the local economy, with high rates of turnover. The resilience of the entire segment shouldn't be confused with the resilience of individual firms. Yet, the fact remains that this segment has been a steady source of manufacturing jobs in the city, currently offering more than 180,000 formal jobs. Moreover, its importance has only grown in the past 20 years. In 1995, it represented $14 \%$ of jobs, while in 2016 micro-manufacturing firms offered $20 \%$ of jobs in the sector. This reinforces how relevant micromanufacturing has become to understanding the contemporary metropolitan economy in general and the new roles of manufacturing in the city more specifically. 


\section{Production chains and geographies of micro-urban manufacturing}

In this section, I examine micro-urban manufacturing activity in São Paulo by dissecting its sector composition. My goal is to provide a more detailed understanding of the different types of small-scale production spaces in the city, in order to avoid generalizations and give concrete insights into the multifaceted segment of micro-urban manufacturing and the diversity of production chains in which it is embedded. First, I will present my findings regarding the breakdown of micro-manufacturing firms into sub-sectors, highlighting the clothing industry as a key sector for micro-manufacturing. Next, I will introduce and analyze two distinct forms of spatial organization, which I am call geographies, of small production spaces in the city: (1) a pattern of distribution that spreads throughout the city, and (2) a pattern where the units are dispersed only in certain parts of the city.

\section{Production chains}

The segment of manufacturing businesses with 1-20 employees is considerably diverse (Figure 7). Around $70 \%$ of the jobs are spread more or less evenly throughout multiple sectors: production of metal, chemical, and electrical products; food and beverages; printing; furniture; and so on. According to a recent survey of micro- (1-20 employees) and small- (20-100 employees) manufacturing companies in the State of São Paulo, around $70 \%$ of the products of these companies are sold directly to final consumers (SebraeSP, 2015, p. 5). Examples of this type of product - that the consumer can buy directly from the producer - can range from biscuits, chocolate, and packaged juice manufactured through the use of small cooking equipment to furniture produced in workshops and metal components assembled in machine shops that one might need when building or renovating a house.

On the other hand, there's still a significant portion of the production of micromanufacturing firms that is sold to other links in larger production chains, and not to final consumers. These products are usually highly specialized, attending to a niche industry. A micro-manufacturing company in the chemical sector, for example, could provide laboratories and other businesses with special and custom-made chemical products, obtained through specific and highly-controlled processes of purification. Another example is a metalworking business that produces metal pipes and bushings that can be used by a different company that produces machinery and equipment - which, in turn, might also sell their product to larger manufacturing businesses to support their own production processes.

Therefore, there is a multiplicity of sectors that reflects on the variety of ways that micro-urban manufacturing units can be embedded in either networks of final consumer bases or in larger production chains. However, despite the heterogeneity of industries, one particular sector also stands out: the clothing industry, which accounts for $31 \%$ of the 
Figure 7 - Breakdown of manufacturing jobs in formal micro manufacturing companies* by sector - City of São Paulo, 2015
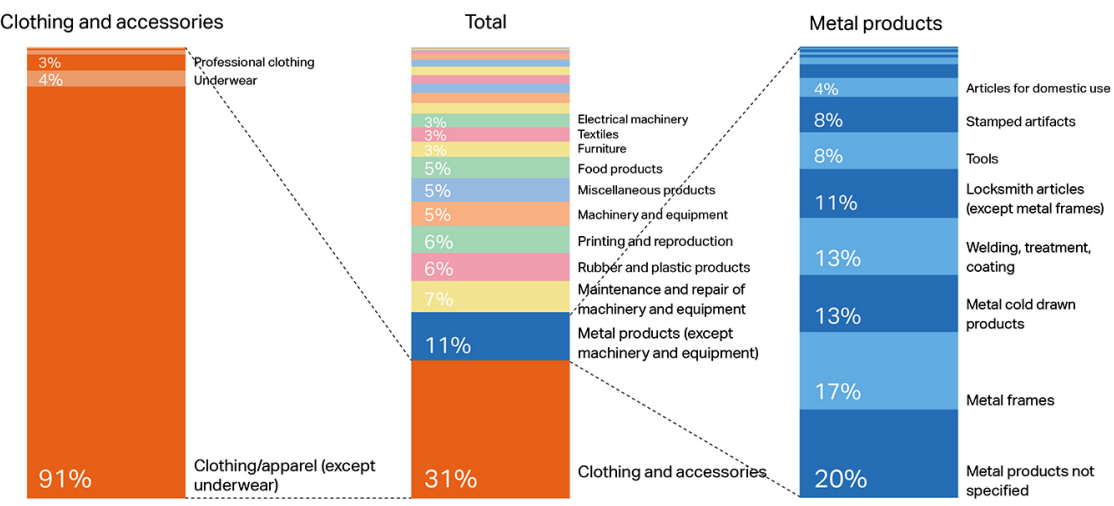

*Companies with 1-20 employees

Source: RAIS/MTE, 2015.

Preparation by: Mendonça Abreu, 2017.

total number of jobs in micro-manufacturing companies. The clothing industry's production chain is still considerably dynamic in the city of São Paulo, concentrating $86 \%$ of the metropolitan region's total number of jobs in the sector, $52 \%$ of the state's, and $14 \%$ of the country's (SMDU, 2013). It is, therefore, an economic activity that highly benefits from being in denser urban areas more broadly, and also one that it is particularly connected to the city of São Paulo. This is mainly due to the availability of a diverse workforce, proximity to final consumers, and a closer connection to current fashion trends that dictate the demand for specific products.

Within the clothing industry, the production space is fragmented into smaller units, with outsourcing at multiple stages of production and a considerable amount of informality (Silva, 2008). Interestingly, the sector in general - not micro-manufacturing units specifically - employs people from diverse education levels, reflecting the different degrees of specialization that are required throughout the fashion and clothing production chain. A little over $60 \%$ of workers in the clothing industry have either no or very few years of schooling, or have only completed middle school. These workers reside at the bottom of the production chain, in positions that require intense labor to produce huge amounts of clothes for little pay. They are often hired through outsourcing practices of other clothing companies. Roughly one-third of these workers have a high school degree, and very few (only about 6\%) have a degree in higher education - they likely work on the creative side of the industry. 
Figure 8 - Trend of manufacturing jobs in formal

micro manufacturing companies by sector -

Metropolitan Region of São Paulo, 1995-2016
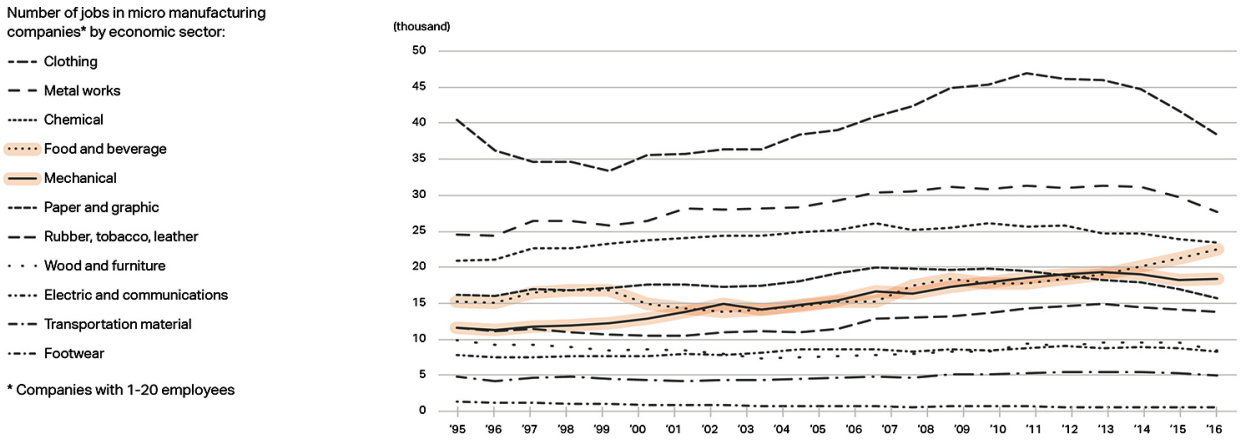

Source: RAIS/MTE, 1995-2016.

Preparation by: Mendonça Abreu, 2017.

Despite its significant share in the overall micro-urban manufacturing landscape, there's also evidence that the number of jobs in the clothing industry have been drastically decreasing since 2010 (Figure 8). On the other hand, different sectors that didn't previously figure so prominently have been rising in importance and number of jobs, such as in food and beverage and mechanical manufacturing companies. One possible explanation for this is that the clothing industry might have been more affected by the economic slowdown that has taken place since 2010 , following the global economic crisis that erupted in 2008. Other sectors, such as food and beverage, might have been less affected - after all, people are more likely to cut clothing rather than meal costs. However, these are only conjectures that need detailed examination.

\section{Geographies}

When we look at the spatial distribution and concentration of micro-urban manufacturing companies by sub-sectors, we find that there are variegated geographies to this segment of economic activity. This means that the inscription of micro-urban manufacturing companies on the territory can't be understood uniformly. There are significant variations that point to different relationships between small and large manufacturers according to economic sectors, or between micro-manufacturing units and their final consumers. The latter depends on the neighborhoods in which these units are concentrated. Briefly, there are two main geographies that stand out: (1) sectors that are be present in most of the city's neighborhoods; and, (2) sectors that appear more concentrated 
in areas of medium- (not necessarily low-) income or closer to industrial zones.

In the first geography identified, which includes economic sectors such as clothing, food and beverage, and paper and graphics, micro-manufacturing companies are located in most of the neighborhoods within what is commonly known as the "expanded center" of São Paulo (Figure 9.1). However, there is a notable exception: these sectors don't appear in more distant peripheral urban areas, such as the extreme eastern and southwestern ends of the city, where a highly concentrated low-income population resides with no job opportunities (Figures 10.1 and 10.2). Even though micromanufacturing units in these sectors appear to contribute to the rebalancing of uneven geographies of employment opportunities, which are highly concentrated in a vector extending from the city center to the southwestern neighborhoods, they do not reach areas that are in most need of investment and jobs.

Figure 9 - Concentration of formal micro manufacturing companies by sector - City of São Paulo, 2015

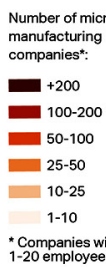

9.1 First geography: distribution more spread throughout the city
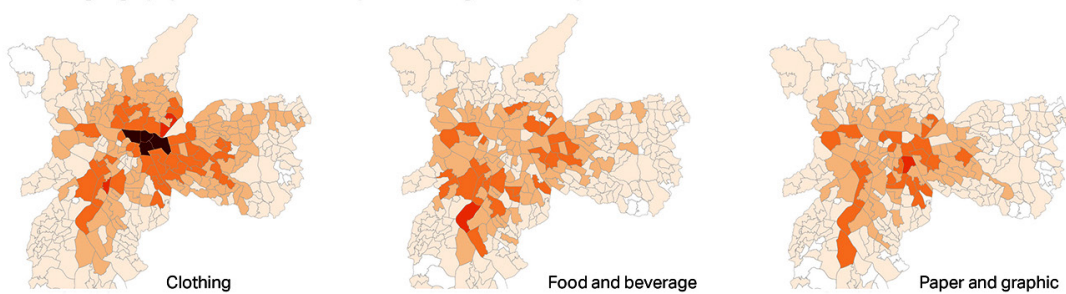

9.2 Second geography: distribution more concentrated in parts of the city
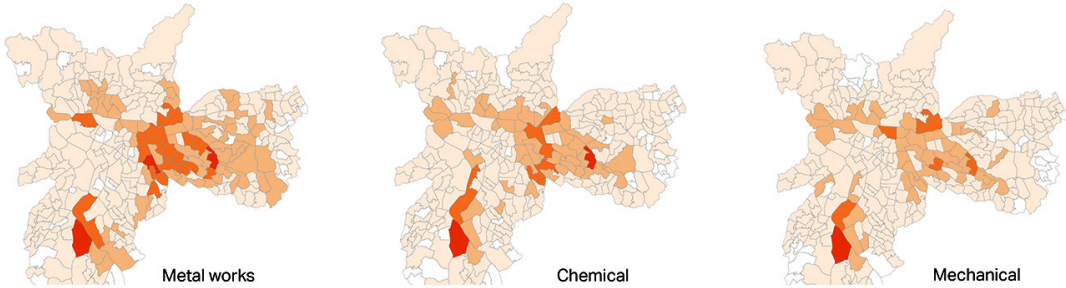

Source: RAIS/MTE, 2015.

Preparation by: Mendonça Abreu, 2017. 
Figure 10 - Distribution of income, employment opportunities and industrial zones - City of São Paulo
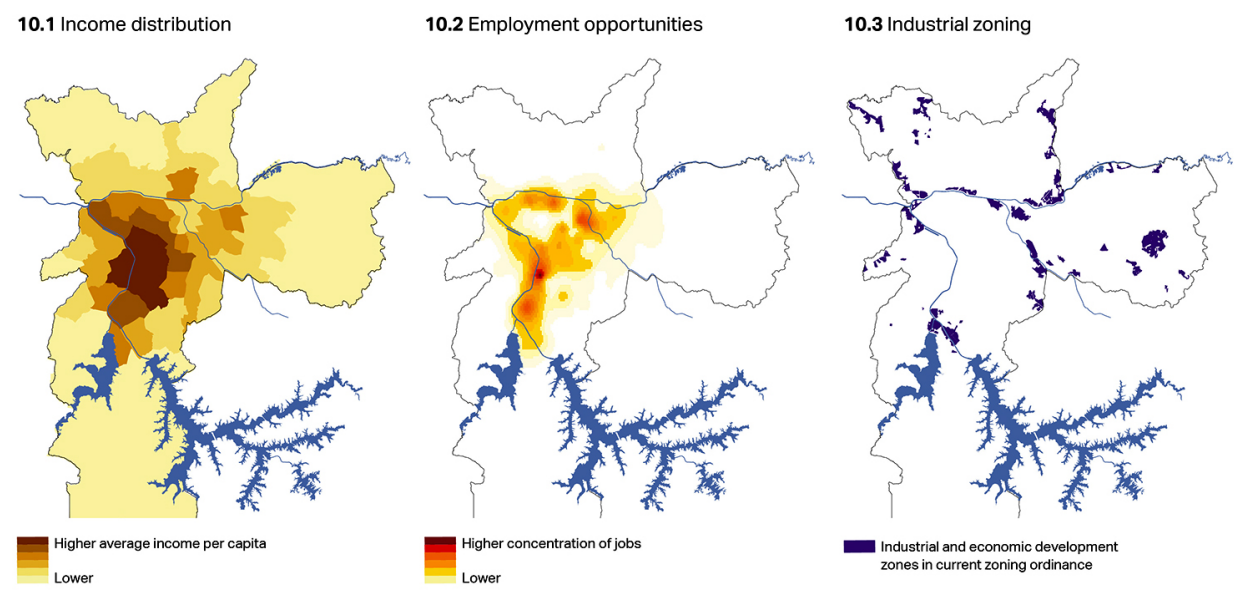

Source: Censo/IBGE, 2010; RAIS/MTE, 2014; Municipal Law 16.402, 2016.

Interesting particularities also arise when looking at individual sectors, such as the large concentration of clothing companies in the city center - in the neighborhoods of Brás, Bom Retiro, and Mooca, where this industry has traditionally existed for many decades. Yet, still, this hasn't prevented micromanufacturing units in the clothing industry from simultaneously spreading to different territories and composing a spatial pattern that is, at the same time, intensely concentrated and dispersed. It also comes as a surprise that the clothing industry is the only one that has micro-manufacturing companies located in more distant eastern neighborhoods. This might be due to the fact that, compared to other sectors, the clothing industry demands little infrastructure and investment to start a production. With a simple sewing machine, one can easily start a small business in the clothing industry. Producing food, beverages, and graphic materials, by contrast, requires specialized equipment and more investment, both in terms of machinery and expertise.

Even if we account for specific areas of concentration, there's a clear overall pattern of distribution that sets these three sectors clothing, food and beverage, and paper and graphics - apart. In order to explain this particular geography, I hypothesize that sectors that are more evenly distributed throughout the city are also the ones that are more directly connected to the final consumers of their products. Some of these manufacturing units are certainly connected to larger production chains. In the clothing industry, for example, there's a significant level of outsourcing. However, it is also easy 
to imagine the entire final product being developed within one small production unit and being sold directly to consumers or to intermediary retailers; in effect, serving a more local network of buyers. A micromanufacturing business in the clothing sector might be able to produce and sell an entire piece of apparel, while another in the food and beverage sector could produce and package different kinds of prepared foods and drinks and sell them directly to final consumers.

The sector that doesn't fit so neatly into this narrative is the paper and graphics sector, which primarily serves other industries by selling packaging material and graphic paper. This leads to an alternative, or perhaps complementary, hypothesis: sectors that appear more evenly distributed share the characteristic of producing less noise and pollution when compared to sectors such as metalworking and the chemical industry. This could explain why they are more broadly accepted in different neighborhoods where commercial and residential uses coexist. More research is needed to carefully investigate each of these hypotheses. But, if they are correct, I suggest the prioritization of these sectors in policies geared towards creating more diverse and mixed-use urban spaces.

The second geography reveals a pattern of spatial distribution that is significantly less ubiquitous than the first (Figure 9.2). The main sectors that can be classified within this second type of geography are metalworking, chemical, and mechanical industries. Their distribution patterns show striking similarities in the dispersion of micro-manufacturing units along the Tietê and Tamanduateí rivers; sprawling over the eastern region of the city; and some concentrated hotspots along the initial stretch of Pinheiros river to the south. What these spaces have in common is that they mostly overlap with traditionally industrial areas along the main rivers and railway lines that emerged during initial waves of industrialization in the city. Additionally, they are mostly in mediumincome neighborhoods. While they do not touch high-income areas, some cross into lower-income neighborhoods.

The fact that this set of manufacturing sectors is not as widely dispersed in the urban fabric influences average commute times of workers. Even though the census data includes all people who are identified as workers in these sectors - and not specifically in micromanufacturing firms - the distribution of travel time from residence to workplace shows that these workers usually take longer to get to work than those who work in the sectors that present a more dispersed distribution in the city. Around $40 \%$ of workers in the clothing, food and beverage, and paper and graphics sectors take less than 30 minutes to get to work - a relatively short amount of time, considering the average commute time in São Paulo of 43 minutes, according to a report from IPEA. $^{7}$ In contrast, around $30 \%$ of workers in the metalworking, chemical, and mechanical sectors spend less than 30 minutes for their commute. The difference is particularly relevant when we look at the mechanical sector: about $50 \%$ of the workers in this sub-sector have a commute from home to workplace of more than 1 hour.

Following the hypotheses proposed above that explain the more dispersed pattern of the first geography, I argue that in the case of metalworking, chemical, and mechanical 
industries, micro-urban manufacturing firms tend to produce more noise and pollution. Consequently, they are less accepted in residential and wealthier neighborhoods. Moreover, I speculate that the reason they are more intensely concentrated in traditionally industrial areas is that these micromanufacturing firms might depend on a direct connection to larger manufacturing units.

This, in turn, raises a relevant policy implication: if we can differentiate between micro-manufacturing businesses that depend on proximity to larger units - either for obtaining raw materials or providing offerings to other industries as a supplier - from those that do well by themselves - either because they don't rely on this proximity on a daily basis or because they only need the direct connection to final consumers - then we can also develop more appropriate industrial and economic development policies for the city. If we identify a sector where micro production units depend on larger manufacturing firms, then policies aimed at maintaining or stimulating the small firm must also promote the adjacent large one.

From a theoretical perspective, these findings add nuance to theories of urban economies. In the 1970s, Milton Santos proposed the theory of two circuits to explain the structure of urban economies in developing countries. This still very influential theory described an "upper" circuit that used capital intensively and was technologically modernized, as well as a "lower" circuit of small scale, labor-intensive activities (Santos, 1978). These two distinct circuits, nevertheless, operated through reciprocal relations. In some ways, my findings on microurban manufacturing activities reinforce
Santos's theory. The micro-scale of these activities enables them to spread throughout urban space and become entrenched in diverse neighborhoods. They have a very different geographical presence than large-scale manufacturing firms, which are more concentrated in industrial zones. Furthermore, micro-manufacturing firms are usually closer to final consumers and offer a large range of products in the local market, similar to the role played by the "lower" circuit, as described by Santos, in urban economies.

On the other hand, micro-urban manufacturing activities are not a monolithic object and, therefore, cannot be entirely explained by the concept of a "lower" circuit. The findings presented in this paper help create a picture of micro-manufacturing firms that is marked by diversity and heterogeneity. There are multiple typologies, geographies, and relationships, depending on the sub-sector under consideration. In some industries, micromanufacturing firms locate more closely to larger-units (or the "upper" circuit), which implies a stronger connection between them. Others are more independent and spread throughout, disconnected from regional production chains. In some sub-sectors, micromanufacturing units are technologically advanced and use high-end machines, while others still rely on labor-intensive activities. In sum, the establishment of different networks of outsourcing after the flexibilization of Fordist modes of production, the diffusion of and easier access to technology, and the increased formalization of micro-manufacturing activities have all blurred the boundaries between "upper" and "lower" circuits. The scale of a firm doesn't necessarily imply a "lower" 
or "upper" circuit anymore. These general processes, as well as my specific findings on micro-urban manufacturing, disrupt the dichotomy proposed by the theory of two circuits and point to the changing role of small production spaces in metropolitan areas.

\section{Conclusion}

My goal for this study was to uncover an element that is usually left out of larger narratives about manufacturing and cities: the scale of micro-urban manufacturing activities. Through a case study of São Paulo, I retraced the historical underpinnings of the relationship between space and economy in the city and highlighted key debates about the role of manufacturing in São Paulo; unearthed the role of micro-production firms and jobs in the overall manufacturing sector; and explored the heterogeneous sectors and geographies of micro-manufacturing.

First, there is an extensive and pervasive network of significantly small manufacturing units spread throughout the city, accounting for $80 \%$ of manufacturing firms and $20 \%$ of the sector's jobs. Its relevance to the metropolitan area is expanding as it steadily grows in number of jobs and firms, despite economic crises and the departure of larger units from the city. Second, micro-urban manufacturing is highly diversified in terms of sectors, as it extends to food and beverage, paper and graphics, chemical, metal works, and mechanical sectors. The clothing industry, however, is a main source of jobs, accounting for $30 \%$ of the total. Furthermore, these sectors form two distinct geographies: one that is more evenly dispersed and another that remains connected to traditional industrial areas, as well as to the eastern region of the city.

This study is far from exhaustive. It is an opening, an invitation, and a provocation for more research on small-scale production in metropolitan areas. Here, I focused on analyzing the quantitative and spatial data that was available, which was restricted to formalized firms. It is also worth noting that there are high levels of informality in this sector. Therefore, the data on formal activity provides a partial representation of this dynamic. There is a lot left to uncover through grounded investigations of these activities and their role both in the city's economy and in neighborhood vitality. I encourage tracking the stories of these firms and the people behind them, their connections to larger production chains, and further investigating their concrete and individual forms of spatiality. Nevertheless, I hope this initial research inspires new inquiries and provokes shifts in planning practices and conversations.

\section{[I] https://orcid.org/ 0000-0001-8414-0921}

University of California/Berkeley, Department of City and Regional Planning. Berkeley, Estados Unidos da América.

giselle@berkeley.edu 


\section{Notas}

The manuscript was entirely revised by Yanin Kramsky (University of California, Berkeley).

(1) Sebrae is a Brazilian social institution aimed at fostering the development of micro and small enterprises.

(2) I particularly want to thank Akinori Kawata, from the Division of Information Production and Analysis at the City of São Paulo's Department of Urban Development, who generously helped me by providing data for this project.

(3) This section draws largely from the review developed in Mendonça Abreu, 2017.

(4) According to Singer, "In general terms, the participation of the five most important sectors that produce consumer goods fell from $47.3 \%$ in 1949 to $34.9 \%$ in 1959 , while the share of the six most important sectors that produce capital goods rose from $34.9 \%$ in 1949 to $42.7 \%$ in 1959 " (SINGER, 2004, p. 194, my translation).

(5) Between 1940 and 1950, the City of São Paulo's population grew at a 5.18\% annual rate, and $5.70 \%$ from 1950 to 1960 . During the following two decades, the annual population growth rate decreased, even though it was still high: The population grew at a $4.57 \%$ annual rate throughout the 1960 s and $3.69 \%$ in the 1970 s. It was only from the 1980 s onward that the population growth drastically slowed down: Between 1980 and 1991, the average annual growth rate was $1.04 \%$; in the 1990 s it was $0.87 \%$; and, finally, from 2000 to 2010 , it reached an average of $0.79 \%$.

(6) Here, I am referring to a segment that includes micro (1-20 employees in manufacturing and 1-10 employees in retail or services) and small (20-100 employees in manufacturing and 10-50 employees in retail or services) businesses, since most of the secondary data available looks at both of these scales of businesses together. The definition, as well as the data, is from Sebrae.

(7) IPEA is the Institute of Applied Economic Research, a public institution that develops studies and researches to support the federal government in policy-making.

\section{REFERENCES}

ARAÚJO, M. (2001). Reestruturação produtiva e transformações econômicas: Região Metropolitana de São Paulo. São Paulo em Perspectiva. São Paulo, v. 15, n. 1, pp. 20-30.

BIDERMAN, C. (2004). "A expansão do setor terciário". In: SZMRECSÁNYI, T. (org.). História econômica da cidade de São Paulo. São Paulo, Editora Globo.

CASTELLS, M. e PORTES, A. (1989). "World Underneath: the origins, dynamics and effects of the informal economy”. In: PORTES, A.; CASTELLS, M. and BENTON, L. A. (eds.), The informal economy: studies in advanced and lessa developing countries. Baltimore, Johns Hopkins University Press.

CHEN, M. (2014). Informal Economy Monitoring Study Sector Report: Home-Based Workers. Cambridge: WIEGO - Women in Informal Employment Globalizing and Organizing. 
DANIELS, P. W. and BRYSON, J. R. (2002). Manufacturing services and servicing manufacturing: knowledge-based cities and changing forms of production. Urban Studies, v. 39, n. 5-6, pp. 997-991.

MATTEO, M. (2007). Além da metrópole terciária. Tese de Doutorado. Campinas, Universidade Estadual de Campinas.

MENDONÇA ABREU, G. K. (2017). Planejamento urbano e atividades econômicas: balanço das experiências na cidade de São Paulo. Dissertação de Mestrado. São Paulo, Universidade de São Paulo.

MEYER, R. M. P.; GROSTEIN, M. D. and BIDERMAN, C. (2004). São Paulo metrópole. São Paulo, Edusp/ Imprensa Oficial.

MONBEIG, P. (2004). “O crescimento da cidade de São Paulo". In: SZMRECSÁNYI, T. (org.). História econômica da cidade de São Paulo. São Paulo, Editora Globo.

PMSP - PREFEITURA DO MUNICÍPIO DE SÃO PAULO (2016). Parcelamento, Uso e Ocupação do Solo Lei $n^{\circ}$ 16.402, de 22 de março de 2016; zoneamento ilustrado. São Paulo, PMSP.

PRADO JR., C. (1998). A cidade de São Paulo: geografia e história. São Paulo, Brasiliense.

ROLNIK, R. and FRÚGOLI JR., H. (2001). Reestruturação urbana da metrópole paulistana: a Zona Leste como território de rupturas e permanências. Cadernos Metrópole. São Paulo, n. 6, pp. 43-66.

ROY, A. and ALSAYYAD, N. (eds.). (2004) Urban Informality: Transnational Perspectives from the Middle East, Latin American, and South Asia. Oxford, Lexington Books.

SANTOS, M. (1978). O espaço dividido: os dois circuitos da economia urbana dos países subdesenvolvidos. Rio de Janeiro, Francisco Alves.

SASSEN, S. (2001). The Global City: New York, London, Tokyo. Princeton, Princeton University Press.

SCOTT, A. (1988) Flexible Production Systems and Regional Development: The Rise of New Industrial Spaces in North America and Western Europe. International Journal of Urban and Regional Research, v. 12, n. 2, pp. 171-186.

SEBRAE (2014). Participação das micro e pequenas empresas na economia brasileira. Disponível em: http://www.sebrae.com.br/Sebrae/Portal\%20Sebrae/Estudos\%20e\%20Pesquisas/ Participacao\%20das\%20micro\%20e\%20pequenas\%20empresas.pdf. Acesso em: 10 dez 2017.

SEBRAE-SP (2015). A micro e pequena indústria paulista. Disponível em: http://www.sebrae.com.br/ Sebrae/Portal\%20Sebrae/UFs/SP/Anexos/a_micro_e_pequena_industria_paulista.pdf. Acesso em: 10 dez 2017.

SILVA, C. F. da (2008). Trabalho informal e redes de subcontratação: dinâmicas urbanas da indústria de confecções em São Paulo. Dissertação de Mestrado. São Paulo, Universidade de São Paulo.

SINGER, P. (2004). "São Paulo: os últimos 40 dos 450 anos de São Paulo". In: SZMRECSÁNYI, T. (org.). História econômica da cidade de São Paulo. São Paulo, Editora Globo.

SMDU - SECRETARIA MUNICIPAL DE DESENVOLVIMENTO URBANO, PREFEITURA DO MUNICÍPIO DE SÃO PAULO (2013). Indústria da confecção mantêm força em São Paulo e concentra 14\% dos empregos do país: Informes Urbanos. Disponível em: http://smul.prefeitura.sp.gov.br/informes_ urbanos/pdf/28.pdf. Acesso em: 10 dez 2017. 
TOKMAN, V. (1992). "The Informal Sector in Latin America: From Underground to Legality". In: TOKMAN, V. (ed.) Beyond Regulation: The Informal Economy in Latin America. Boulder, Lynne Rienner.

TORRES, H. (2012). Afinal, a desconcentração produtiva é ou não relevante? A cidade de São Paulo no olho do furacão. Novos Estudos - CEBRAP. São Paulo, n. 94, pp. 69-88.

WILLIAMS, C. (2014). "Informal Economies". In: PADDISON, R. and HUTTON, T. (eds.) Cities and Economic Change: Restructuring and Dislocation in the Global Metropolis. London, SAGE.

Texto recebido em 4/jun/2018

Texto aprovado em $7 /$ ago/2018 
